\title{
転移性肝癌と $\alpha$-Fetoprotein
}

\section{$-\alpha$-Fetoprotein 陽性膵癌肝転移 3 例 -}

$\begin{array}{lllllll}\text { 久保 } & \text { 保彦 } & \text { 長田 英輔 } & \text { 橋本 } & \text { 雅晴 } & \text { 加治 久昭 } \\ \text { 有島 } & \text { 恒明 } & \text { 沢 靖 彦 } & \text { 池尻 直幹 } & \text { 下川 } & \text { 泰* } \\ \text { 神代 正道 } & \text { 中井 } & & \end{array}$

要 旨: 原発性肝癌 127例, 転移性肝癌62例, その他各種肝疾患合計 374例の血中 AFP を検索 した．原発性肝癌はその $93.7 \%$, 転移性肝癌は $33.8 \%$ か $20 \mathrm{ng} / \mathrm{m} l$ 以上であった. 転移性肝癌の原 発臓器による AFP 出現率は, 胃癌25例中 $32.1 \%$, 膵癌 14 例中 $35.7 \%$, 胆道癌 7 例中 3 例, 結腸 直腸癌 8 例中 4 例に陽性で，原発巣による出現率に大きな差はみられなかった。

AFP 高值（MO 法陽性）を呈した革癌肝転移の 3 剖検例を報告した.

索引用語： $\alpha$-fetoprotein 原発性肝癌転移性肝癌 膵癌肝転移

\section{緒 言}

$\alpha$-fetoprotein (以後は AFPと略) は Abelev" により 1963年移植肝癌ラット血清中に 発見され，続いて翌年 Tatarinov ${ }^{2)}$ によりヒト原発性肝細胞癌患者（以下 Hepatoma之略）血清中に証明されて以来, Hepatoma の診断 のみならず血中 AFP 濃度の変動から, その予後の推 測，および治療効果判定の指標として久くことのできな い娭査となった。しかし AFP の radioimmunoassay が わが国でも西ら゙，石井ら゙により確立され，低濃度の AFP が検出可能上なり Hepatoma の診断率は向上した が，一方でその特異性が失われ，急性肝炎，慢性肝炎， 肝硬変などの非腫湯性びまん性肝疾患でも一過性にAFP の上梨を示すことが知られている. また転移性の肝癌で あ高値を示す症例があり，とくに胃癌の肝転移でMicroOuchterlony 法でも陽性を示す AFP の高い症例が報告 されている.縢癌の肝転移については，AFPの陽性例の 報告は少ない，われわれは AFP 高値を示し, 剖検によ り確認された肝転移をもつ膵癌 3 例を経験したので報告 するとともに，各種肝疾患，とくに転移性肝癌と AFP について論してみたい.

\footnotetext{
* 久留米大学 第二内科（主任岡部信彦教授）

** 同第一病理（主任中島敏郎教授） $<$ 受付日 49 年 5 月 20 日 $>$
}

\section{検索対象および方法}

AFP 検出の対象となったものはHepatoma 127例（剖 検66例，生検22例）肝硬变64例，慢性肝炎42例，急性 肝炎42例, 転移性肝癌62例（原発巣による内訳は，胃 癌 28 , 膵癌 14 , 胆道癌 7 , 結腸直腸癌 8 , その他 5 ) Cholangioma 7 例の合計 374 例である.

診断は剖検のほか，生検，血管造影，シンチグラフィ -一, 腹腔鏡などにより行なった. 肝硬变で経過中 Hepatoma を併発したものは Hepatoma としてとりあつかっ た. また肞硬変で AFP 值が比較的高值をとる例は血管 造影，シンチグラコィーなどにより Hepatomaの合併が ないことを確認した. 転移性肝癌は全例組織学的診断の ついたものであり，AFP 高值を示したものはいずれる 剖検により Hepatoma の合併がないことを確認してい る. AFP の検出法は micro-Ouchterlony法 (以下 M.O. 法と略)と Radioimmunoassay（以下 RIA）を併用し た. M.O.法に使用した抗血清はAFP陽性 Hepatoma 患 者腹水を涷結乾燥により濃絍後, 硫安塩析により部分 精製し家鬼を兔疫した．家鬼血清の非特異抗体の吸収に は正常とトプール血清をタルタルデハイド処理し， 得られた不溶性蛋白を使用した. RIA は $\alpha$ フェトー 125キット（Dinabot 社）を使用した．高濃度血清は， あらかしめ RIA で陰性であった正常ヒトプール血清で 希釈した後，定量した。検体は duplicate で湘定し， $\gamma$ 
線の計測は Aloka, Autowell Scitillation Counter によっ て行なった.

\section{成 績}

各種肝疾患 376例の RIA による AFP 值を Fig. 1 に 示す. 正常人は総て20ng/ml 以下である. Hepatoma て

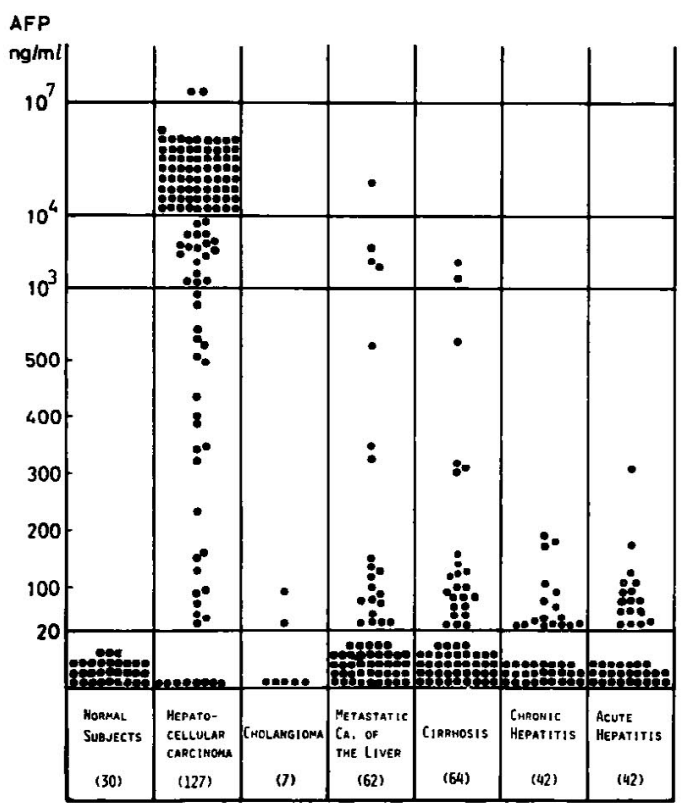

Fig. 1. Serum AFP level in neoplastic and nonneoplastic liver diseases.

は高値をとるものが多いが, 転移性肝癌, 肝便変などで も軽度〜中等度の上昇を示す例が少なくないことがわか る. Fig. 1 は Hepatoma, Cholangioma，転移性肝癌では 初回検査の成縝を示し, 肝硬変, 慢性肝炎, 急性肝炎で は経時的に検查したもののらち，その最高值をあらわし た.

Hepatoma: M.O. 法による陽性率は 127例中91例 陽珄 $(71.7 \%)$ 剖検例だけでは66例中47例陽性 $(71.2$ \%)であった. RIA による定量では20ng/ml 以下の正 常値から $1,788 \times 10^{3} \mathrm{ng} / \mathrm{ml}$ までの広い範囲にわたって分 布し，127例中，119例93.7\% が $20 \mathrm{ng} / \mathrm{ml}$ 以上を示し た. 初回検查のみを図示しているが，一般に腫瘍の増大 ととすに AFP る増加するが， $400 \mathrm{ng} / \mathrm{m} l$ 以下の应例で は経時的に大きな変動を示さない症例が多い.

Cholangioma: すべて $100 \mathrm{ng} / \mathrm{m} l$ 以下で, 7 例中 5 例 は20ng/m $l$ 以下であった.

転移性肝癌 : M.O.法による陽性率は62例中 5 例 8.1

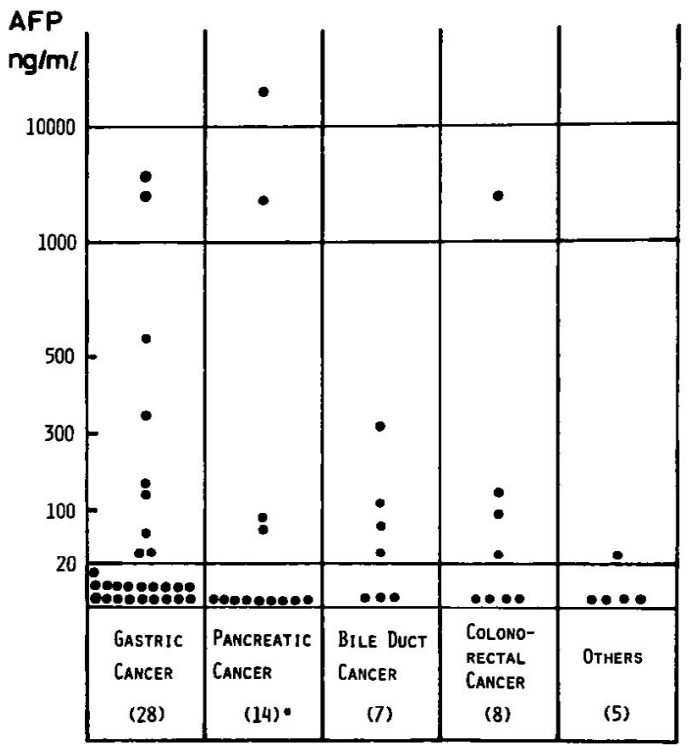

Fig. 2. Serum AFP level in metastatic carcinoma of the liver. * : Case 1 . in this report is included in the 14 cases, but not illustrated in this figure because determination of AFP by RIA was not done.

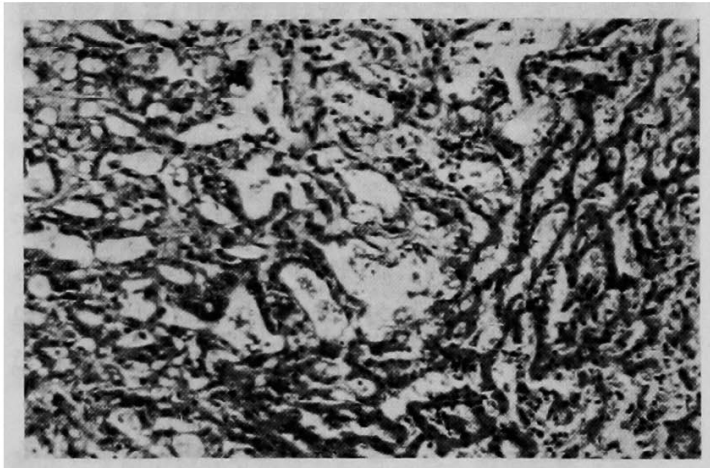

Fig. 3. Case 1. Metastatic adenocarcinoma of the pancreas, showing tubular arrangement, in the liver.

\%)であり，必ずしも低い頻度ではない. $20 \mathrm{ng} / \mathrm{ml}$ 以上 を陽性とするならば，33.8\%にのぼる。しかしその大部 分は $1,000 \mathrm{ng} / \mathrm{m} l$ 以下であった。これを原発巣により分 けてみると，Fig. 2 に示すごとく，胃癌肝転移28例中， 9 例 $32.1 \%$ (この5ち 2 例は M.O. 法陽性), 膵癌肝転 移14例中 5 例 $35.7 \%$ (うち 3 例は M.O. 法陽性)，胆道 癌 7 例中 3 例 $42.9 \%$, 直腸結腸癌肝転移 8 例中 4 例 $50 \%$ （ちち M.O.法陽性 1 例）であった. な打直腸結晹癌で 


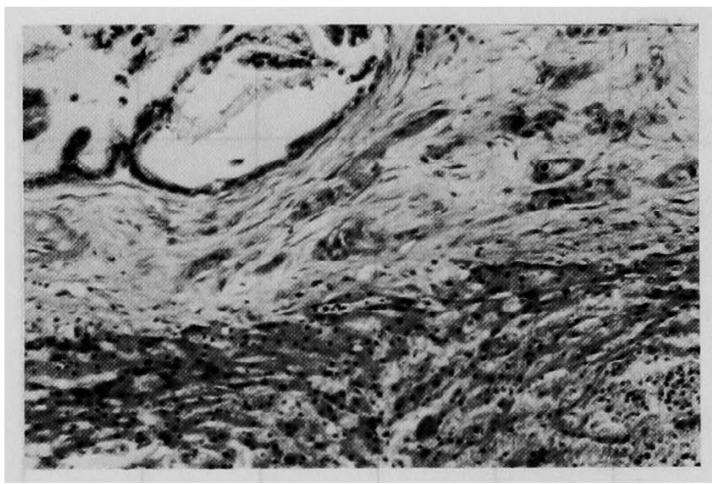

Fig. 4. Case 2. Metastatic adenocarcinoma of the pancreas, Showing cystic tubular arrangement with marked stromal proliferation, in the liver.

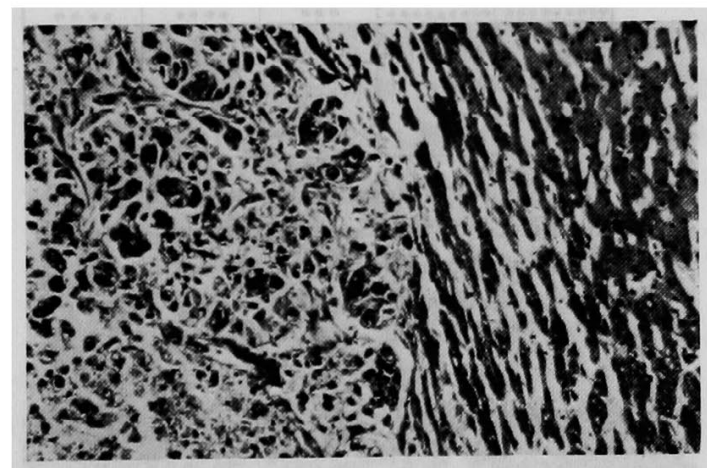

Fig. 5. Case 3. Metastatic carcinoma of the pancreas, showing pleomorphism, in the liver.

M.O. 法陽性を呈した 1 例は胃癌との重複癌で，胃癌で 陽性となった 1 例と同一症例である. 剖検の結果からも いずれに由来する肝転移か，決められなかった．その他 4 例のうち AFP 軽度上昇を示した症例は乳癌肝転移で あった.

非埂湯性肝疾患では Fig.1のごとく AFP が上昇する 例が少なくない，肝硬変 $37.5 \%$, 慢性肝焱 $40.5 \%$, 急性

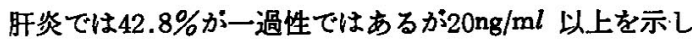

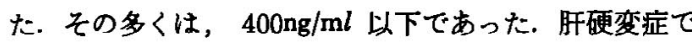
は64例中 2 例が M.O.法陽性を示したが，この2症例は 剖検により：Hepatoma の：合併のないことを確認してい る.一般に非腫䨚性びまん性肝疾患のAFPは一過性の上 昇で経過とともに下降した. $2 \sim 3$ 週の間隔で， 3 回以 上 AFP が $400 \mathrm{ng} / \mathrm{m} l$ 以上を呈したばあいは Hepatoma の存在を考虑し検索するべきであろう.

$$
\text { 症例 }
$$

一般に転移性肝癌の AFP 值は比較的低値をとるが，
15巻 9 号 (1974)

以下に述べ 3 症例は従来報告が少ない膆癌の肝転移で AFP 高値を示した症例である (M.O. 法陽性)。転移性 肝癌に批り AFP 産生機序解明の上でむ何らかの参考 になると思われるので報告する.

症例 1 : 小○田 $\bigcirc$ 郎, 72歳, 男, 染物工.

主訴：食欲不振，体重減少。

既往歴・生活歴に特記すべきことはない。

現病攵：昭和 44 年 8 月より全身倦总感を自覚した. 10

Table 1. Laboratory examinations of the three autopsied cases of the pancreatic carcinoma with liver metastasis.

\begin{tabular}{|c|c|c|c|}
\hline & Case I & Case II & Case III \\
\hline RBC & $260 \times 10^{4}$ & 331 & 395 \\
\hline $\mathbf{H b}$ & $10.5 \mathrm{~g} / \mathrm{d} l$ & 10.6 & 11.5 \\
\hline WBC & 10,500 & 6,500 & 12,400 \\
\hline ESR & $8 / 30$ & $37 / 77$ & $42 / 80$ \\
\hline TTT & 0.4 & 7.6 & 4.2 \\
\hline $\mathrm{ZnTT}$ & 6.9 & 28.6 & 11.8 \\
\hline T. Bil. & $0.25 \mathrm{mg} / \mathrm{d} l$ & 0.3 & 0.3 \\
\hline D. Bil. & 0.15 & 0.15 & 0.2 \\
\hline T. Prot. & $6.0 \mathrm{~g} / \mathrm{d} l$ & 7.8 & 7.6 \\
\hline Alb. & $48.0 \%$ & 42.0 & 43.8 \\
\hline$\alpha-1$ & 9.3 & 6.0 & 7.0 \\
\hline$\alpha-2$ & 10.7 & 11.0 & 17.6 \\
\hline$\beta$ & 9.3 & 7.0 & 10.5 \\
\hline$\gamma$ & 22.7 & 34.0 & 21.1 \\
\hline T. Chol. & $143 \mathrm{mg} / \mathrm{d} l$ & 158 & 225 \\
\hline Al-P & 15.7 K.A.U. & 10.5 & 9.1 \\
\hline GOT & 24 & 13 & 44 \\
\hline GPT & 12 & 7 & 18 \\
\hline LDH & 1,195 & 540 & 2,500 \\
\hline Isozyme 1 & $21.0 \%$ & N.D. & 15.9 \\
\hline 2 & $34.2 \%$ & & 41.9 \\
\hline 3 & 22.5 & & 27.3 \\
\hline 4 & 13.9 & & 11.9 \\
\hline 5 & 8.4 & & 3.0 \\
\hline Amylase & $(35-150)$ & N.D. & $\frac{178}{(130-400)}$ \\
\hline BSP $45^{\prime}$ & $13.4 \%$ & $\left(\mathbf{I C G}_{15^{\prime}}\right)$ & 2.5 \\
\hline BUN & $18.2 \mathrm{mg} / \mathrm{d} l$ & 25.0 & 16.0 \\
\hline HB-Ag (CEP) & N.D. & negative & negative \\
\hline$\alpha$-Fetoprotein & M.O.(t) & $\begin{array}{c}53,000 \\
\mathrm{ng} / \mathrm{ml}\end{array}$ & 4,000 \\
\hline
\end{tabular}


月より上腹部鈍痛，食欲不振を来たし対症的治療のみを 受けていたが，体重減少（約10kg）腹部部満に加えて下 肢浮腫を生じ，45年 1 月 22 日当科に入院した。

入院時所見：全身るい瘦し，黄㡺を認めず，軽度貧血 性，表在リンハ節を触れず，胸部は理学的所見に異常を 認めず，肺肝境界第 6 肋骨，心简部にて硬い肝を 4 横指 触知, 軽度の腹水を認めた。 下肢浮腫は中等度.

臨床検查所見および経過：臨床検查所見は Table 1 K 示した. 経過とともに Al-P はしだいに上昇し, 死亡前 には27.3となったままたDH の上昇が著明であった. AFP は M.O. 法のみしか行なっていないが陽性であっ た. 転移性肝癌が疑われたが一般状態が悪く，診断のつ かぬまま入院後20日目に死亡し剖検された。

剖検診断

1）原発性膵荿癌（体部，腺癌）

2）転移：肝，左肺，膵周囲リンバ節

病理学的所見：畽瘍は膵体部にあり，一部周困組織と 着している.肝は $1,750 \mathrm{~g}$ で大豆大から拇指頭大の多 数の転移巣を認める. 組織学的㵏腫浧は間質線維組織 に富む腺癌で大小種々の腺管を形成し, 粘液産生すみら れる. 肝転移巣でも同じ組織像を呈し，非癌部の肝組織 には軽度の炎症細胞浸潤がみられる。

症例 $2:$ 橋 $\bigcirc$ 吟 $\bigcirc, 65$ 歳, 女.

主訴：体重減少，全身陸急.

既往歴：10年前に薬物性肝障害, 若い、頃から関節りウ マチ.

現病歴：昭和46年夏より体重減少が目立ちはじめ（6 カ月間に約 $17 \mathrm{~kg})$ ，ときに心蒚部痛を自覚するようになっ た. 11月下旬, 心筒部に腫瘤を指摘され，胃透視乞の他 の結果より胃癌およびその肝転移と猃断され，47年 1 月 9 日入院した.

入院時所見：ややるい瘦し，貧血，黄疸を認めず，表 在性リンバ節を触知せず，脈70整，心音純，呼吸音清，

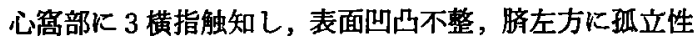
の鵴卵大の腫瘤を触れた，浮腫を認めず，諸検查所見は Table 1 のと㧊りであるが，軽度の貧血を認め，TTT， ZnTT の高值, $\gamma$-globulin の上昇があり, Al-P, GOT, GPT は正常範围内にあり，Al-P は経過とともに增加の 傾向はあったが，その最高値は14.5であった. LAP む 正常範囲内にあった．黄疸は全経過を通じてみられなか った. フミラーセは測定していない，肝腫大はしだいに 堌大し，入院後 7 月で全身衰弱により死亡した。

\section{剖検診断}

1）原発性膵藏癌（体部～星部, 腺癌）

2）転䔟：肝，両肺，脾，両副腎，リンパ節（肝内部, 大動脈周囲，膵周团，肺内部）

病理学的所見：腫瘍は膵体部から尾部にかけてあり， 胃浆膜と固く空着し，一部筋層内へ浸潤している.肝は重 量1,800g で大豆大から拇指頭大の数個の転移がある.組 織学的には腫瘍は大小種々の腺管形成を示す腺癌で㙘死 㑯向が強い。肝転移巣でも同じ組織像を示し，非癌部の 肝組織には軽度の脂肪変性と炎症細胞浸潤がみられる.

症例 3 : 吉 $\bigcirc \bigcirc, 25$ 歳, 女.

主訴：左頝部の有痛性腫瘤, 腰痛.

既往歴：10年前りウマチ性心臓病.

現病歴：昭和 47 年 5 月 3 日第 2 子を満期出産, 産後 3 日目より腰痛および徽熱が出現，また 5 月10日より右下 肢が疼痛のため歩行困難となった。腰痛は鎮痛郕により 軽減していたが，5月30日，左預部に有痛性の埂瘤を生 じ，熱は $38^{\circ} \mathrm{C}$ 台になるとともに左季肋部痛，呼吸困難を 生し， 6 月14日当科に釈介され入院した.

入院時所見：体格中等度，栄美良好，体温 $37.4^{\circ} \mathrm{C}$, 脈 120 , 血圧 106/74, 軽度貧血性, 黄疸を認めず, 左䅡 部に弾力性硬な拇指頭大のりンパ節と思われる腫瘤を触 れる. 心音は収縮期性雑音田度，呼吸音清，肺肝境界第 6 肋間, 腹部は全体に圧痛があり，心蒚部から右季肋部 にかけて凹凸不整な腫痹を触れる．浮腫は認めず，神経 系に異常を認めない。

臨床検查所見および経過：臨床検查所見は Table 1 示すが LDH の著明な上昇が特徽的で，また Al-P が正 常籁囲内にあることが，前の 2 例と合わせて，転移性肝 癌としては比較的特異な所見と思われる。

上腹部の腫瘤は日に日に增大し, 同時に肝も入院後 1 週間で 3 横指触知するようになった．両側肺はX線上， びまん性肺転移を思わせる米粒大の散布性陰影を認め， 呼吸困難はしだいに増強した．左䅡部リンバ節の摘出 標本では, Medullary type の carcinoma の転移であっ た. また骨髄穿刺標本でも anaplastic type の癌細胞の 転移を多数認めた，貧血が急速に增強するととるに，白 血球25,600, 分類で Myel. 2, Meta. 2, St. 29, Seg. 64, Eo. 0, Ba. 0, Mono 2, Ly. 1, 血小板 44,000 , 網 状赤血球 $25 \%$ 之類白血病反応を示し，出血偭向とともに Thromboelastography，福武法により線溶の亢進を認め， 血管内凝固症候群を訅断された。血清 AFP は M.O. 法陽性， 4,000ng/ml であった。 
原発巣不明の全身びまん性転移を来たした消化器癌と 診断し，マイトマイシン $\mathrm{C}$ ，副腎皮質ステロイト等を投 与したが，入院後16日目に死亡し剖検された。

\section{剖検診断}

1）原発性搼澸癌（体部～尾部・未分化癌）

2）全身の広範な転移：肝，脾，両側肺，両側副腎，大 腸, 全身各所のリンパ節

病理学的所見：董韵は膵体部から尾部にかけてあり，

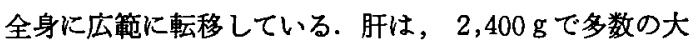
豆大および 2 個のクルミ大の転移巣がある. 組織学的に

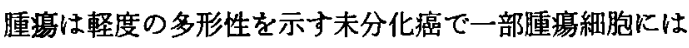
領食能がみられる.

\section{考案}

Abelev ${ }^{1)}$ に上り担旰癌ラット血清に AFP が発見され たのは1963年であるが，その翌年にはも5 Tatarinov ${ }^{2)}$ によりヒト肝癌患者血清中に AFP の存在することが明 らかにされ，Hepatoma の診断に AFP の測定が急速

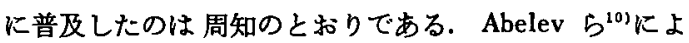
り辠丸の Teratoma 患者血清にもAFP の存在すること が報告されたが, AFP は Hepatoma に非常に特異性の 高い物質であると考えられていた．その後 Bourreille

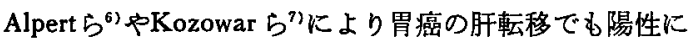

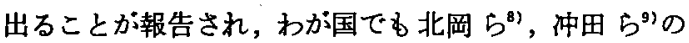
報告をはじめとして胃癌肝転移では AFP 陽性を示すこ とがあれではないことが明らかになっている。，一方，

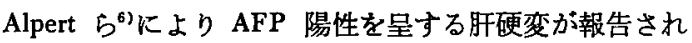
て以来, 急性肝炎, 慢性肝炎, 肝硬变などの非腫瘍性び まえ性肝疾患でも一過性ではあるが，AFP 陽性を示すこ とが相ついで報告されている，さらに RIA によるAFP の定量か導入され， $20 \mathrm{ng} / \mathrm{m} l$ の低濃度の測定が可能にな ると, AFP の Hepatoma への特異性は失われた. しか し，AFP の量的変動和よび経時的変動を考虑するとな お Hepatoma への特異性は非常に高い。

転移性肝癌に批ける AFP は陽性であっても一般には 低值のものが多く, 少数例が M.O. 法でも陽性を示寸程 の高値を示す.このことは診断上の問題のみならず， AFP産生機序解明の上からも非常に興味のあるところで ある.

Abelev ${ }^{10)}$ の集計によると転移性肝癌 334例中 AFP 陽 性は2 例， $0.6 \%$ の陽性率で低率である. 本邦では向島 $5^{111}$ は 31 例中 1 例（胃癌転移）が陽性, 遠藤 $5^{12}$ は 60 例 中 2 例陽性, 石井 $5^{133}$ は 48 例中全例陰性, 冲田 ${ }^{91}$ K上 ると76例中 4 例が AFP 陽性であった，われわれの成續
では58例中 5 例 $(8.6 \%)$ 陽性 で比較的高率であった が, 北岡 $5^{8)}$ 子68例中 7 例 $(10.3 \%)$ に陽性で，胃癌の 旰転移のみについてみると，42例中 $16.6 \%$ 陽性であっ たと報告している.これらの成績はいずれる M.O.法を 主体とした寒天ゲル内沈降反応による成續であるがRIA 法によると陽性率はさらに高くなる，石井ら ${ }^{13}$ は222例中 7 例 $(31.8 \%$ ) に AFP の上昇を認め，われわれの症例 では58例中 20 例 $34.5 \%$ と高率に陽性であった．との多く は $1,000 \mathrm{ng} / \mathrm{m} l$ 以下の比較的低值を示すものが多いが, AFP 出現頻度は必ずしも低くはない。

AFP 陽性を示す転移性肝癌の原発巣についてはBourreille $\mathrm{e}^{5)}$ 以来胃癌を原発とするものの報告がもっとも多 く，その他前立腺，直腸などが知られており，膵原発に

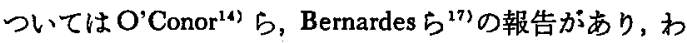
が国では赤井の集計 ${ }^{15}$ とよれば 2 例の AFP 陽性膵癌 肝転移が知られている(このうち 1 例は本論文の症例 1 である). AFP 陽性転移性肝癌は本邦でる胃癌が圧倒的 に多く，土屋ら しかしこれは本邦では消化器癌のうち胃癌が开倒的に多 いことを考虑すると，胃癌肝転移の AFP 陽性率が他の 転移肝癌に比し必ずしも高いとはいえないであるう。事 実われわれの成績は先に Fig. 2 に示したごとく，原発巣 に上る分頑では胃癌 $34.6 \%$, 愺癌 $38.5 \%$, 胆道癌 7 例中 4 例, 直晹癌 8 例中 4 例，之の他 4 例中 1 例であって, AFP出現率に原発甈器に上る大きな差はみられない上ら である.このことは AFP 産生機序を解明する上で非常 に興味あることである.

AFP の産生機序および産生部位については蛍光抗体 法，ペルオキシダーゼ抗体法などにより Hepatoma で は尰瘍細胞の一部が産生していることは知られている。 また急性肝炎の回復期, 慢性肝炎, 肝硬变でも一過性に AFP が陽性になることがわかり，肝細胞の再生過程で AFPを産生すると考えられている。このことは転移性肝 癌において，肝細胞が転移巣による压迫，血行障害など による肝細胞障害に引き統く再生時，あるい恃未知の癌 細胞由来の物質による影響を受けて AFP を産生するこ とも充分あり得よ5．土屋ら ${ }^{16)}$ の胃癌肝転移例で，癌組 織抽出液のみならず，非尰瘍部組織からる AFP を抽出 していることは，この事実を支持するるのと思われる。 残念ながらわれわれの 3 症例ではいずれも組織内 AFP の証明はなされていないが，肝の非癌部に組織学的に著 明な変化がないこと，AFP 濃度がびまん性肝疾患のそ れよりはるかに高いことから AFP は主として転移巣で 
産生されたるのと推測される.

転移性肝癌の血清 AFP の量的な点についてみると, 一般に $1,000 \mathrm{ng} / \mathrm{m} l$ 以下のものが大部分であり，Hepatoma以外の肝疾患に拈ける血清 AFP と大体同じ範囲内 にあり，少数例が高值を示す.このよらに高值を示す症 例は Hepatoma の合併が考えられるが，われわれの症例 でも，またその他の報告例でも剖検により Hepatoma の 合併は否定されている.

組織学的に AFP 陽性例と陰性例に特徵的差巽がある か否かは興味がある. 北岡ら゙) の報告した 7 例の胃癌肝 転移例で共通した組織は易様癌であり，細胞は多形性に 富み，精細胞癌や胎児性癌に類似した構造を認めてい る. 冲田ら”は AFP 陽性胃癌肝転移 2 例で, その肝腫瘍 部の組織像は，腫場細胞が充実性胞巣を形成し，索状に 配列し，Hepatoma の組織像に酷似していると述ぺてい る.しかしこのような類似性を認めない報告もあり ${ }^{16)}$,わ れわれの症例でも Hepatoma との類似性は見られず，組 織像と AFP 産生能の関係は推測の域を出ないであろう.

AFP の出現は悪性腫瘍のいわゆる先祖返りの一つと 考えられるが，AFP の機能の解明を含めて 代謝面での アプローチが待たれる.

\section{結語}

1）原発性肝細胞癌，転移性肝癌その他各種びまん性肝 疾患の $\boldsymbol{\alpha}$-fetoprotein の出現率を micro-ouchterlony 法 および radioimm・unoassayにより検討した.

2）転移性肝癌の $\alpha$-fetoprotein 出現率は原発巣による 差はあまり大きいものではなく，およそ30５0\%に AFP の上昇を認めた。

3）AFP 高值（M.O.法陽性）を示し，剖検により確認 された脄癌肝転移 3 例について報告した。

岡部信彦教授の御校閱に深謝いたします。

\section{交 献}

1) Abelev, G.I., Perova, S.D. et al.: Production of embryonal $\alpha$-globulin by transplantable hepatoma. Transplantation., 1: 174, 1963.

2) Tatarinov, J.S.: Detection of embryospecific $\alpha$-globulin in the blood sera of patients with liver tumor. Vopr. Khim., 10: 90, 1964 (Chem. Abst.).

3) 西 信三,近藤宇史他 : Radioimmunoassay によ る肝癌拉よび他疾患における $\alpha$-フェトプロテ
インの検出. 医学のあゆみ, $80: 822,1972$.

4) 石井 勝 : Radioimmunoassay 法による $\alpha$ - ᄀ エトプロテインの臨床的意義. 医学のあゆみ, $80: 823,1972$.

5) Bourreille, J., Mateyer, P. et al.: Existence d'alphafoetoproteine au cours d'un cancer secondaire du foie d'origine gastrique. Presse Med., 78: 1277, 1970.

6) Alpert, E., Isselbacher, K.J. et al.: Alphafetoprotein in a patient with gastric carcinoma metastatic to the liver. N. Engl. J. Med., 285: 1058, 1971.

7) Kozower, M., Fawaz, K.A. et al.: Positive alpha-fetoglobulin in a case of gastric carcinoma. N. Engl. J. Med., 285: 1059, 1971.

8) 北岡久三, 服部信他 : $\alpha$-fetoprotein と転移性肝 癌, 胃癌との関連. 医学のあゆみ, $79: 129$, 1971.

9) 沖田 極，西岡幹夫他： $\alpha$-Fetoprotein に関す る研究. 肝蔵, $13: 421,1972$.

10) Abelev, G.I.: Alpha-fetoprotein in ontogenesis and its association with malignant tumors. Adv. cancer Res., 14: 295, 1973.

11）向島達他： $\alpha$-Fetoglobulin による原発性肝癌の 診断. 肝臓, $11: 325,1970$.

12）遠藤康夫他：RI 法による $\alpha$-Fetoprotein の臨 床的意義. 内科, $30: 225,1972$.

13) 石井 勝他： $\alpha$-Fetoprotein $の$ 検出法之 臨床的 意義. 日本臨床, $30: 1220,1972$.

14) O'Conor, G.T., Tatarinov, J.S. et al.: A collaborative study for the evaluation of a serologic test for primary liver cancer. Cancer, 25: 1091, 1970.

15）平井秀松： $\alpha$-Fetoprotein $\sigma$ 基礎的，臨床的意 義. 臨床科学, $19: 353,1973$.

16) 土屋雅春，亀谷㥍与隆他： $\alpha$-Fetoprotein 異常 高值を示した Borrman III 型胃癌肝転移例. 日 消会誌, $70 ： 475,1973$.

17) Bernades, P. et al.: Présence de l'alphafoeto-protéine sérique dans quatre cas de cacers digestifs primitifs autres que l'hépatome. Presse Med., 79: 1585, 1971. 


\title{
Serum Alpha-Fetoprotein and Metastatic Carcinoma of the Liver
}

\author{
Kubo Yasuhiko, Nagata Eisuke, Arishima Tsuneaki, Hashimoto Masaharu,* \\ - Kaji Hisaaki, SAwa Yasuhiko, IkejIRI Naoki, Shmokawa Yutaka, \\ KoHjrRo Masamichi \& NakaI Shun**
}

Serum alpha-fetoprotein (AFP) was studied in 374 cases with neoplastic and non-neoplastic liver diseases including 127 cases with hepatocellular carcinoma and 62 cases with metastatic carcinoma of the liver. Determination of AFP was carried out by microOuchterlony double immunodiffusion technique and radioimmunoassay.

AFP level higher than $20 \mathrm{ng} / \mathrm{m} l$ was demonstrated in the sera of $93.7 \%$ of patients with hepatocellular carcinoma, $33.8 \%$ of those with metastatic liver carcinoma, 2 out of the 7 with cholangiocellular carcinoma, $42.8 \%$ of those with acute hepatitis, $40.5 \%$ of those with chronic hepatitis and $37.5 \%$ of those with liver cirrhosis. The serum alpha-fetoprotein level was higher than $20 \mathrm{ng} / \mathrm{ml}$ also in 9 of the 27 gastric, 5 of the 14 pancreatic, 3 of the 6 bile duct and 4 of the 8 colono-rectal carcinoma patients with liver metastasis. Normal subjects showed less than $20 \mathrm{ng} / \mathrm{ml}$.

Three autopsied cases of the pancreatic carcinoma with liver metastasis which had showed high serum AFP concentration (double immunodiffusion positive) were reported; in these cases, no histological similarity of the pancreatic carcinoma to hepatocellular carcinoma was observed.

\footnotetext{
* Second Department of Medicine, Kurume University School of Medicine (Fukuoka).
}

** First Department of Pathology, Kurume University School of Medicine (Fukuoka). 